The University of San Francisco

USF Scholarship: a digital repository @ Gleeson Library |

Geschke Center

Economics

College of Arts and Sciences

2011

\title{
The Economics of Parenting, Self-Esteem, and Academic Performance: Theory and a Test
}

Rajeev Darolia

Bruce Wydick

University of San Francisco, wydick@lucas.usfca.edu

Follow this and additional works at: http://repository.usfca.edu/econ

Part of the Economics Commons

\section{Recommended Citation}

Rajeev Darolia and Bruce Wydick. The Economics of Parenting, Self-Esteem, and Academic Performance: Theory and a Test .Economica (April 2011), vol. 78, issue 310, pp. 215-239. DOI: 10.1111/j.1468-0335.2009.00802.x

This Article is brought to you for free and open access by the College of Arts and Sciences at USF Scholarship: a digital repository @ Gleeson Library | Geschke Center. It has been accepted for inclusion in Economics by an authorized administrator of USF Scholarship: a digital repository @ Gleeson

Library $\mid$ Geschke Center. For more information, please contact repository@usfca.edu. 


\title{
The Economics of Parenting, Self-Esteem, and Academic Performance: Theory and a Test
}

\author{
JEL Classification Codes: C70, I21, J13 \\ Keywords: Parenting, Education, Motivation \\ Rajeev Darolia* \\ Bruce Wydick**
}

November 2008

\begin{abstract}
This paper develops a theory about how signals sent to a child by an altruistic parent affect a child's self-esteem, effort and long-term performance when a parent has better information about child ability than children do themselves. We carry out OLS, 2SLS, and 3SLS estimations of our model on a sample of 651 college students. Our results show some complementary actions before college, such as parental praise, foster academic achievement above what natural ability would predict. Conversely, we find some substitutionary actions before college, such as providing them cars as gifts, are associated with lower effort in college and underachievement.
\end{abstract}

*George Washington University and Charles River Associates, 1201 F Street, NW, Washington, DC 20004, e-mail: rdarolia@gwu.edu.**Professor of Economics, University of San Francisco, 2130 Fulton Street, San Francisco, CA 94117 e-mail: wydick@usfca.edu. 


\section{INTRODUCTION}

Why is it that successful people are often the most confident, with high levels of self-esteem and ambition? Are elevated levels of self-esteem a function of a person's success? Or is success itself at least partly a function of an individual's self-esteem, influenced by other factors such as parenting and family upbringing? Our paper hypothesizes that signals communicated in the process of parenting influence the sense of worth and motivation of children later in their adult life. We show that the origin of these signals lies in certain fundamental characteristics of both parents and children, and trace the process by which these characteristics influence behavior of altruistic parents toward their children, and how the resulting parental behaviors later affect the behavior of their children in college academics. In short, children with a welldeveloped sense of self-esteem may achieve more because they develop an incentive to try harder, believing that effort put into a task will ultimately reap a high payoff.

Social psychology has long examined the role of motivation and confidence in the propensity to undertake or succeed in a given task (Deci, 1971; Condry and Chambers, 1978; Henderlong and Lepper, 2002). Recently, economics has introduced new tools to investigate the effects of incentives on performance (Kreps, 1997; Bénabou and Tirole, 2003; Kremer et al., 2004). Our research adds to the growing body of literature bridging social psychology and economics by focusing on the relationship between self-esteem and achievement. In this paper, we present a simple Parent-Child model that incorporates aspects of both principal-agent and signaling frameworks. From our model we derive a mapping of outcomes for children based on child and parental types. We then test some of the implications of the model with first-hand data obtained from 651 university students.

Our paper considers the relationship between self-esteem, effort, and achievement. In the typical scenario, a principal--a manager, parent, teacher, or coach--has a vested interest in the amount of effort an agent--an employee, child, student, or player--exerts in an activity. The principal can attempt to motivate performance by convincing the agent of a suitable return to effort, possibly through providing rewards or demonstrating confidence in the agent's ability to succeed in the task. Now consider an agent who is less informed about her true ability than the principal. She will use the signals from the principal as a means of 
learning about herself and the potential payoff of effort into the task. Thus, the principal's attempts to motivate the agent exert both direct and indirect influences: directly from the payoff provided for completing the task, and indirectly through the agent's reflective inference of the signal sent by the principal's actions toward her. It has been argued in the literature that empowering and encouraging an agent can effectively send signals of confidence and raise self-esteem, which may raise achievement (Bénabou and Tirole, 2003). Conversely, "per contract" rewards or excessive forms of assistance may introduce extrinsic motivation that dominates an agent's own intrinsic ambition (Deci, 1971; Lepper et al., 1973; Kreps, 1997).

In the context of the parent-child relationship, opinions vary on what is most responsible for a child's achievement. The area has been a main theater for the well-known nature vs. nurture debate; some research finds that inherited skills are the most important factors, whereas other studies show environment to be a predominant influence. Mueller and Dweck (1998) find through experimental methods that the type of praise a parent displays for a child matters. Praise for intelligence tends to undermine academic initiative, while praise for effort encourages it. There is evidence that parents with higher levels of education will have children who are better educated (Black et al., 2005; Oreopolous et al., forthcoming). Still in question is whether naturally smart parents simply have naturally smart kids or if higher levels of intelligence and/or education better prepare parents to raise children who succeed academically. While the question is important, our main focus is not to enter into this debate. Instead, the paper assumes both nature and nurture play a role, taking differences in innate ability as given, and examining the influence parents and parenting can have on achievement levels of children.

Our hypothesis posits that a parent can provide two broad types of contributions that will have divergent effects on child academic achievement. The first type is complementary to the child's own effort, will serve to foster the child's skills, self-esteem, and motivation, and should therefore encourage overachievement relative to a child's basic intelligence. The second type is substitutionary to the child's internal drive and undermines achievement relative to inherent ability. One might ask why a parent would ever choose the second type of behavior, but the answer is simple. An altruistic parent cares not just about the achievement of a child, but also about the welfare of the child. For this reason our model conveys the idea that based on 
the parent's own attributes and a (pessimistic) view of a child's ability, an altruistic parent may choose to directly provide for a child rather than motivate her to achieve on her own.

Our empirical work attempts to relate the costs and benefits of these contrasting behaviors to the economic endowment, psychological temperament, and child-rearing approach of the parent. Students were asked to describe the psychological temperament of their parents and examples of parenting behaviors in specific areas. We use behaviors of the parent toward the student during childhood as independent variables along with a list of pre-existing family characteristics to examine their relationship to the components of achievement. We describe student achievement as measured by grade point average (GPA) as a function of inherent intelligence, which we estimate with a twenty-question intelligence quotient (IQ) test, student effort level, and academic skill (which we compute as a residual based on GPA minus IQ and effort). "Overachievers" are thus students who rank highly in GPA relative to IQ either because they exert more effort and/or have higher academic skill.

The results from our estimations indicate that children who grow up with parents who praise them regularly exert a significantly greater effort in school work at the college level, such that on average they become overachievers relative to their natural IQ. We also find that children whose parents read to them overachieve on average, not through increased effort, but through enhanced scholastic ability. Furthermore, we find that while the dollar amount of a child's weekly or monthly allowance prior to college may exert neutral or negative effects on academic effort in college, children who were given an allowance only for the completion of a specific task display increased effort in college. Children whose parents purchased them a car in high school display a lower effort level. Moreover, controlling for parental behaviors, we find little significant relationship between parental income, education, or number of siblings and grade-point average, IQ, academic effort level, scholastic ability, or "overachiever" status.

The rest of the paper is organized as follows: Section I gives an overview of existing literature on the transmission of human capital, intrinsic and extrinsic motivation, and the determinants of educational achievement. Section II describes our parent-child model, while Section III provides an overview of survey design and data. Section IV presents and interprets estimated econometric results, and Section V concludes. 


\section{RELATED LITERATURE}

Our research draws from two primary existing veins of literature. The first examines the positive and negative effects of intrinsic and extrinsic motivation. The second focuses on the demographic and environmental determinants of educational achievement.

\section{A. Intrinsic and Extrinsic Motivation}

Bénabou and Tirole (2003) discuss the effects of rewards and empowerment on self-esteem and motivation. They study the connection between an individual's motivation and her social environment in a variety of relationships, including manager and employee, teacher and student, and parent and child. Illustrated in a principal-agent model, the agent may be uncertain of the payoff to a particular action proposed by the principal, and therefore will undertake the action or provide a high level of effort only if she is sufficiently confident of success in the task. The principal's goal is to therefore increase the agent's selfconfidence in the assignment. Since there are unknowns to each party (for example, the agent's raw ability may be known better by the agent, the difficulty of the project known better by the principal) the agent will look for overt and private signals in order to ascertain the attractiveness of the task. In almost all environments, the agent relies on the "looking glass self" (Cooley, 1902) to infer private information from signals of the principal, and therefore garner information about herself. This framework may be especially salient in the parent-child relationship, as the child may believe the parent knows more about her than herself, and so will weigh signals from her parent heavily in updating her type.

There has been substantial literature (Deci, 1971; Lepper et al., 1973) claiming that rewards for tasks are weak or even negative compellers to action. Assistance and high extrinsic motivation offered by a principal may serve to lower an agent's self-esteem, decrease intrinsic motivation, and create dependence.

Bénabou and Tirole (2003) demonstrate that under asymmetric information intrinsic motivation may decrease with the level of an extrinsic bonus if the agent is unsure of her ability. Conversely, they show that lower incentives may actually signal greater trust in the agent, increasing self-esteem and intrinsic motivation. Extrinsic incentives may be effective in a workplace setting, where relationships are relatively short and immediate results often outweigh any long-term effect. However, in our context, a parent is not only 
concerned with the temporary outcome of tasks for their child, but also more likely valuing sustained effort and long-term success.

Henderlong and Lepper (2002) argue that praise may be a compelling motivator in many instances, such that, "Provided that praise is perceived to be sincere, it is particularly beneficial to motivation when it encourages performance attributions to controllable causes, promotes autonomy, enhances competence without an overreliance on social comparisons, and conveys attainable standards and expectations."

Extrinsic incentives, however, may also matter, even in academic settings. Kremer, et al. (2004) find that girls in Kenya experienced significant increases in tests scores when they were eligible for a merit scholarship program. Not only did scores increase immediately, but the gains remained in the year after the competition. Moreover, the students' attitudes towards school or their own abilities appeared unaffected. This positive longer-term result contrasts with the previously discussed models emphasizing negative extrinsic motivation. Thus the literature seems to indicate that both intrinsic and extrinsic incentives can have ambiguous effects, and it is not fully understood in which contexts the positive and negative effects dominate.

\section{B. Determinants of Educational Achievement}

A number of studies in psychology and sociology have associated parental support for academic progress at home, particularly in reading, with academic achievement in school. In a controlled experiment, Lembert (1985) finds mothers' time with a child reading, teaching a child colors, and telling her stories is significantly associated with a child's reading performance in school. She also finds a positive association between the mothers' expectations of educational achievement and actual achievement.

Haveman and Wolfe (1995) provide an extensive review on the existing literature on determinants of schooling attainment and achievement, finding large and statistically significant effects across studies of parental time into a child's educational process, such as parental school involvement, reading materials in the home, and adherence to religion. Moreover, the authors find that the magnitude of the effects of direct parental input into education dominate the much smaller effects of incentives created by both markets and governments for increased investment in schooling by children. 
Fryer and Levitt $(2004,2006)$ find that racial gaps in academic achievement could be due to parental or environmental influences, difficult summer situations, or that the standards of measurement (often standardized testing) do not accurately assess the skills of minorities. The authors find that socio-economic status and the number of children's books in the home are positive factors associated with both higher reading and math test scores. But their empirical evidence also supports the hypothesis that school quality has a strong influence in achievement and that determinants of divergence between children cannot be purely attributed to background and parenting.

\section{THE MODEL}

Consider a game between two players who we will refer to as the Child and the Parent. ${ }^{1}$ The game shares some characteristics with a standard principal-agent framework. The Parent (principal) has certain parameters under her control that influence the effort level of a Child (agent), the effort level affecting an outcome that matters to the Parent. However, the model differs from the standard principal-agent framework in that the Parent is altruistic; he cares about the utility of the Child, and in fact incorporates the Child's utility function into his own.

The model also incorporates some facets of a standard signaling game. However, it differs in that in the typical signaling game, the sender has knowledge of his or her own type that is hidden to the receiver, and therefore sends a signal to the receiver in order to communicate his type. In contrast, our model considers the opposite case. The Child (receiver) is unsure of her own type, but the Parent (sender) knows the Child's type, as well as his own. Of central importance is this asymmetric information gap between the two parties, in which messages from the Parent can override the Child's view of herself. These messages from the Parent may be calculated or unintentional, but are communicated with the Child's interest in mind. Because the altruistic nature of the Parent is common knowledge, the Child views the Parent's messages as a superior judgment of her (the Child's) true type. Since the Child has an evolving self-concept of her own aptitude, she may supersede her own prior self-view with her interpretation of the Parent's view, which then contributes to her self-esteem. 
[INSERT FIGURE 1 HERE]

The timing of the game is as follows and is shown in Figure 1. Nature chooses a natural ability, or type, for the Child, $\theta_{i} \in\left\{\theta_{L}, \theta_{H}\right\}$ for a given activity such as schooling, athletics, artistic, or musical talent, where $\theta_{L}$ represents low ability and $\theta_{H}$ represents high ability with probabilities $p_{L}$ and $p_{H} \equiv 1-p_{L}$, respectively. ${ }^{2}$ The parameter $\theta_{i}$ is an input for an activity that is complementary to effort in producing success, probably best described as "giftedness."

The Parent, with a vested interest in the utility of the Child, decides how to respond to the Child's type, either through offering "encouragement," $n$, "assistance," $s$, neither, or both, such that $n \in\{\underline{n}, \bar{n}\}$ and $s \in\{\underline{s}, \bar{s}\}$. In this way, the Parent chooses a low or high amount of resources to devote to encouragement or assistance to the Child. "Encouragement" is intended to represent actions by the Parent that affirm the Child's ability and effort in a given activity, such as school, music, or athletics. Encouragement involves investing the necessary amount of time and effort to help convince the Child of her own capability in undertaking the given activity.

In some cases, the Parent may have an interest in affirming the Child's capability in (for example) school, when the Child is not truly a gifted type. All else equal, however, the Parent has a greater incentive to encourage the truly gifted Child, since giftedness and effort are complementary, making increased effort by the gifted Child pay larger dividends than increased effort for a less-gifted Child. Thus, greater encouragement builds the Child's self-esteem, making her believe that any level of effort will display a greater marginal return than otherwise.

"Assistance," unlike encouragement, is a substitute for a child's own effort. It can take various forms depending on the activity. For younger children in elementary school, it may take the form of leading a child to answers on a homework problem, or directly helping the child carry out much of the difficult work on a project. It may involve offering a higher allowance if the child seems unable to earn money on his own by working for others, or giving an allowance without expectation for household chores in return. Assistance 
may also take the form of various interventions, but its defining characteristic is to make sure that "everything turns out O.K." for a child.

The following examples help clarify the difference in parenting approaches we describe. An "encouraging" parent tells a child that her natural brilliance means that effort devoted to schoolwork will yield good grades. An "assisting" parent solves many homework problems for the child. An "encouraging" parent exhorts her child to obtain a part-time job so that she can save to buy a car. An "assisting" parent buys the car for the child to make sure she has adequate transportation. For older children in their later teens and twenties, assistance may specifically take the form of direct financial transfers, perhaps resulting from a fear that the child will be unable to achieve financial independence as a result of her own performance in college or post-high school training.

In some cases actions taken by the parent may be difficult to categorize. For example, is the hiring of a math tutor or a music teacher encouragement or assistance? But the general distinction is that one type of action encourages effort while the other substitutes for a desired outcome. We will see that both encouragement and assistance can be rational actions by an altruistic parent, but that they also indirectly affect a child's selfesteem (belief about her own type). Encouragement adds to the child's self-esteem, while assistance subtracts from it.

The Parent's type is given in the model by costs of providing $\bar{n}$ and/or $\bar{s}$ for the Child, $v_{j} \in(0, \tilde{v}]$ and $\sigma_{j} \in(0, \tilde{\sigma}]$ respectively, independently distributed across the population of Parents. The Parent's type is thus defined by $v_{j} \times \sigma_{j} \rightarrow \theta_{j}$. The Parent has perfect knowledge of his own type, but the Parent's type is hidden information to the Child.

We posit that heterogeneity in $\theta_{j}$ across Parental types may be influenced by two broad categories of characteristics: psychological and economic. Consider first differing psychological attributes of the Parent. It may be that $v_{j}$ is related to a Parent's own self-esteem, i.e. it is more difficult for a Parent with low self-esteem to encourage a Child, or involve higher psychic costs, as in Spence (1974). A Parent with higher self-esteem (low $v_{j}$ ) may simply have greater emotional resources at his disposal for encouragement. Additionally, it 
could be that power or patronage plays into the relationship such that it may make a low-type Parent feel better to make a Child who is a high type believe that she is also a low type, a kind of "Stepmother/Cinderella" phenomenon.

Our paper also incorporates the possible effect of a Parent's temperament, or "psychological type," in particular the difference between the Jungian perception functions, Sensation (S) and Intuition (N) (Jung, 1920). The perception functions are considered dominant, described as the "fundamental dimension of human difference," while the judging functions (Thinking, T and Feeling, F) and the attitudes (Judgment, J and Perception, P) are considered auxiliary (Keirsey and Bates, 1984). Using these functions to separate the four temperaments as discussed in Keirsey and Bates (1984) we explore how differences between the preferences of sensitive (Dionysian, SP/Epimethean, SJ) and intuitive (Apollonian, NF/Promethean, NT) types will shape parental responses to their children.

In Jung's framework, the sensitive Dionysian (SP) and Epimethean (SJ) temperaments find it easier to render assistance through their focus on "today." The Dionysian temperament is focused on immediate action and performance, rather than preparation for tomorrow. In contrast, both the intuitive Promethean (NT) and Apollonian (NF) types share goals of attaining higher knowledge and a broad range of abilities, rather than immediate performance. "As with the NT, the NF is future-oriented and focused on what might be" (Keirsey and Bates, 1984). The Apollonian type is naturally more apt to cultivate potential in others and actualize the abilities of those around them. The Promethean type possesses a love of intelligence and attainment of abilities, often vital to long-term achievement.

While these represent important psychological attributes, economic attributes of the Parent may also influence $\theta_{j}$. The building of self-esteem in the Child is a significant function of a Parent's time devoted to the nurturing and affirmation of the Child (Gecas and Swchalbe, 1986), and for this time-investment by the Parent there is often little substitute. But as a Parent's wage increases, the opportunity cost of spending time with children increases, while the time opportunity cost of providing assistance to the Child decreases. A Parent with a lucrative profession may therefore find the opportunity cost of esteem-building encouragement of the Child higher than a Parent with a more modest income. 
As Bénabou and Tirole (2003) point out, there do exist cases in which direct help from a principal may be indicative of high ability, such as if an agent's higher type is complementary to direct assistance when an agent knows the principal's own payoff is increasing in the level of help. Being aware of such cases, however, we will focus on the first and perhaps more common case, in which the provision of direct aid to the Child communicates to her that the outcome from her own effort may be insufficiently low.

The Parent chooses $n \in\{\underline{n}, \bar{n}\}$ and $s \in\{\underline{s}, \bar{s}\}$ in order to maximize his own payoff, $U_{p}$, which is a function of the utility of the Child less the costs of encouragement and assistance, where $d_{n}=1$ if $n=\bar{n}$ and $d_{s}=1$ if $s=\bar{s}$, and both variables are equal to zero otherwise.

$$
U_{p}=U_{c}-v_{j} d_{n}-\sigma_{j} d_{s}
$$

The Child's utility is a function of the net rewards accruing from his or her own effort, less the cost of this effort (where the marginal disutility of effort is normalized to one), and from the assistance (transfer) received from the Parent.

$$
U_{c}=\theta_{i} \cdot \ln (e)-e+s
$$

Based on the actions of the Parent, the Child updates her belief regarding her type, or her self-esteem. Let $E[\theta \mid n, s]=\hat{\theta}$, where $\hat{\theta} \in\left\{\theta^{\bar{n} \bar{s}}, \theta^{n \bar{s}}, \theta^{\bar{n} \underline{s}}, \theta^{\underline{\underline{\underline{s}}}}\right\}$. The Child then chooses an effort level $e^{*} \in\left\{e^{\bar{n} \bar{s}}, e^{\underline{\underline{n}} \bar{s}}, e^{\bar{n} \underline{\underline{s}}}, e^{\underline{\underline{n}} \underline{\underline{s}}}\right\}$ that maximizes $E\left[U_{c}\right]=\hat{\theta} \cdot \ln (e)-e+s$, and $s=\bar{s}$ if assistance is rendered and zero if $s=\underline{s}$. For simplicity, we assume the effects of encouragement and assistance on Child self-esteem are independent, i.e. $\hat{\theta}^{\bar{n} s}-\hat{\theta}^{\underline{n} s}=\hat{\theta}_{\bar{n}}>0$ for $n \in\{\underline{n}, \bar{n}\}$ and $\hat{\theta}^{n \bar{s}}-\hat{\theta}^{n s}=\hat{\theta}_{s}<0$ for $s \in\{\underline{s}, \bar{s}\}$. Figure 1 provides a schematic of the game.

First, note that the optimal effort of the Child will correspond to her belief about her type, $\hat{\theta}_{i}$. The Child will choose $e$ to maximize $E\left[U_{c}\right]=\hat{\theta} \cdot \ln (e)-e+s$, which yields the first-order condition $\frac{d E\left[U_{C}\right]}{d e}=\frac{\hat{\theta}}{e}-1=0$, or that $e^{*}=\hat{\theta}$. Defining $e^{\bar{n} s}-e^{\underline{n} s} \equiv e_{\bar{n}}$ for $n \in\{\underline{n}, \bar{n}\}$ and $e^{n \bar{s}}-e^{n s} \equiv e_{\bar{s}}$ for $s \in\{\underline{s}, \bar{s}\}$, and using this result we obtain the following: 
LEMMA 1: A high-ability Child, $\theta_{H}$, is more likely to receive encouragement by a Parent than a low-ability Child, $\theta_{L}$.

PROOF: By equations (1) and (2), the Parent will encourage the Child if $v_{j}<\theta_{i}\left(\ln \hat{\theta}^{\bar{n} s}-\ln \hat{\theta}^{\underline{n} s}\right)-e_{\bar{n}}$, which given $v_{j} \in(0, \tilde{v}]$, is more likely to hold for $\theta_{H}$ than $\theta_{L}$

LEMMA 2: A lower ability Child, $\theta_{L}$, is more likely to be provided assistance by a Parent than a high-ability Child, $\theta_{H}$.

ProOF: By equations (1) and (2), the Parent will assist the Child if $\sigma_{j}<\theta_{i}\left(\ln \hat{\theta}^{n \bar{s}}-\ln \hat{\theta}^{n \underline{s}}\right)-e_{\bar{s}}+s$, which given $\sigma_{j} \in(0, \tilde{\sigma}]$ and noting that $\left(\ln \hat{\theta}^{n \bar{s}}-\ln \hat{\theta}^{n \underline{s}}\right)<0$, is more likely to hold for $\theta_{L}$ than $\theta_{H}$.

By using LEMMAS 1 and 2 and a straightforward application of Bayes Rule, it can be shown that $p\left(\theta_{H} \mid \bar{n}\right)>p\left(\theta_{H} \mid \underline{n}\right)$, or that the Child, who does not know her own type or the Parent's type, knows she has a higher probability of being a high type if she has received encouragement from the Parent. Similarly, it is easily shown that, $p\left(\theta_{H} \mid \bar{S}\right)<p\left(\theta_{H} \mid \underline{S}\right)$ or that the Child knows she has a lower probability of being a high type given that she has received assistance from the Parent. The following proposition follows from these results:

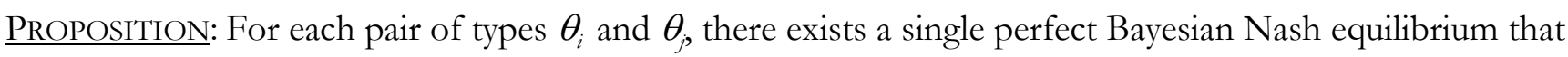
yields an optimal pair of actions for the Parent $\left\{n^{*}, s^{*}\right\}$ and an optimal level of effort, $e^{*}$ for the Child. PROOF: Let the set of ordered pairs of Child's and Parent's types $\theta_{i} \times \theta_{j}$ be given by $T \subset \mathfrak{R}^{3}$, and let the set of ordered pairs of Parent actions $n \times s$ be given by $A \subset \mathfrak{R}^{2}$. Further, let $f: T \rightarrow A$, represent the mapping of the Child and Parent types into the pair of actions by the Parent, and $g: A \rightarrow \hat{\theta}$ represent the mapping of the actions of the Parent into the beliefs of the Child about his type, where $\hat{\theta} \in \mathfrak{R}^{1}$. Since $f$ and $g$ are both functions, then the product function $h \equiv f \circ g$ is also a function. Thus, $h: T \rightarrow \hat{\theta}$ 
represents a function that yields a unique level of self-esteem $\hat{\theta}$ for the Child for every ordered pair of types in T. Since by LEMMA $1, e^{*}=\hat{\theta}$, there exists a single perfect Bayesian Nash equilibrium set of actions $\left\{n^{*}, s^{*}\right\}$ and $e^{*}$ for each pair of Child-Parent types, $\theta_{i}$ and $\theta_{j}$.

The results of LEMMAS 1 and 2 and the Proposition can be used to create the behavioral mappings found in Figures $2 \mathrm{~A}$ and $2 \mathrm{~B}$, which yield self-esteem and achievement behavior of Children as a function of $T=\theta_{i} \times \theta_{j}$ The cutoff points in the maps, $v_{1}, v_{2}, \sigma_{1}$ and $\sigma_{2}$, are obtained from LEMMAS 1 and 2. Eight different resulting Child behaviors are derived in the mapping.

The classes of behaviors among highly gifted children include (1) Gifted Underachievers who receive little encouragement but much assistance from parents; (2) Independent High Achievers, who receive little encouragement or assistance; (3) Dependent High Achievers, to whom parents provide ample amounts of both encouragement and assistance; and (4) Highest Achievers, gifted types who receive ample encouragement but little assistance from parents.

\section{[INSERT FIGURE 2A HERE]}

\section{[INSERT FIGURE 2B HERE]}

Among the less-gifted also merges four classes of behaviors: (1) Material Dependents, less-gifted types who receive large amount assistance, but little encouragement from parents; (2) Independent Low Achievers, receiving little encouragement or assistance; (3) Material and Emotional Dependents, to whom parents provide large amounts of encouragement and assistance; and (4) Emotionally Dependent Overachievers, those who perform a level that surpasses their natural giftedness as a result of strong encouragement (but little assistance) from parents.

\section{DATA DESCRIPTION}

We test some of the implications from our model using a survey administered to 651 undergraduate and graduate students conducted in classrooms at the University of San Francisco during the fall semester of 2005 and the spring semester of 2006. Table 1 displays summary statistics from the sample. Students reported ages of 17 to 48 with an average age of 21.37. The sample included 92 graduate students from classes in economics, business, and education and 559 undergraduate students from economics, psychology, 
history, business, language, science, and education. Students reflected the wide ethnic diversity of the university: 52\% were European or Anglo Americans, 33\% were Asian or Asian American, 10\% were Latino, and 5\% were African or African American. We sought a random sample of targeted students by surveying a variety of complete classes.

While surveys were voluntary in compliance with the protection of human subjects, in the majority of classes, all students in attendance for a particular course participated in the study. In courses where some students declined to participate, statistics were compared against total population for possible bias, but none was found. Students who are missing data on undergraduate GPA or did not take the IQ test were dropped from the sample. We recognize that there is likely to be some amount of homogeneity of the data, given all subjects were students at the same university. However, the ethnic diversity of the university mitigates this problem, allowing for more variation in the sample than might exist elsewhere. US News \& W World Report ranks it in the top 25 most ethnically diverse national universities, where the university is classified as "selective," with an average undergraduate SAT score of 1150 . We also recognize the qualms some researchers maintain over the use of IQ tests as a measure of raw intelligence, despite their widespread use in academic research. However, given the lack of alternatives, the fundamental nature of many of the questions (many of which dealt with shape and pattern recognition), and the broad distribution of outcomes on our 20-question test $\left(\mu=9.85, \sigma^{2}=7.84\right)$, we feel that the test was able to capture important variations in raw intelligence. Survey Design

The subjects were asked to fill out a two-part survey, which took approximately twenty minutes. Students were first given ten minutes to complete a twenty-question test, based on aptitude problems used to measure IQ, including verbal, abstract reasoning, quantitative, and visual-spatial questions. ${ }^{3}$ After the IQ test, students were given an indefinite amount of time to complete a 48-question survey. The students were asked questions about their current grade point average, their self-reported level of effort in university coursework, as well as their parents' personality characteristics, approaches to parenting, different types of actions their parents took related to academic activities, if and under what conditions they received rewards or allowance, whether their parents had purchased them a car, income and educational data about their parents, and other 
similar questions. The survey incorporated controls for parental education and income since they have been found to be significantly associated with educational achievement in past literature (see review by Haveman and Wolfe, 1995). Other variables used as controls include age, race, undergraduate or graduate student status, and number of siblings.

We included questions in the survey about students' perception of their own intelligence and their perceptions of their parents' perception of their intelligence, finding that students considered themselves a little more intelligent than their peers, but not as intelligent as they believed their parents think them to be. ${ }^{4}$ About $59.1 \%$ of students responded that "I try hard in school, but not as hard as I could," whereas only 25.5\% said "I try hard to do my best." Students more often received rewards for success (33.7\%), rather than effort $(20.8 \%)$, on academics.

We included three parental personality questions to reflect parents' psychological temperaments After reviewing the responses, we felt that the question "Which best describes your father (mother)? A) Accepted you who you are; or B) Pushed you to reach your potential" best summarized the distinction between a strongly intuitive parent (Apollonian/Promethean) in contrast to the sensitive parent (Dionysian/Epimethean) in the context of our theory (we used a composite score including other parental temperament questions in some of our estimations which yielded very similar results). In our estimations we also included dummy variables to indicate whether a parent had ever helped the student cheat on an assignment, had ever completed the majority of a school assignment for the child, and whether the student as a child had received allowance without having to complete some task or chore.

\section{EMPIRICAL ESTIMATION AND RESULTS}

To examine causes of achievement, we disaggregated different components of academic success. Achievement in school (as measured by GPA) is a function of intelligence (IQ), academic effort, and “academic skill," best described as "how good one is at school." We assume a GPA production function such that $G P A=F(I Q$ Academic Effort, Academic Skill). Each observation is given a percentile score that corresponds to the rank respective to that category. GPA Percentile is the percentile rank for the student's 
reported undergraduate GPA at the time of survey. ${ }^{5}$ IQ Percentile is the percentile rank for the student's score on the problem-solving test. Academic Effort measures the student's reported level of effort to do college academic work well. We calculate Academic Skill, the relatively intangible proficiency in study skills and productivity of academic work, as a residual from a regression of GPA on IQ and Academic Effort. ${ }^{6}$ We also convert this residual into a percentile rank. Of course, students will also perform better when they have selected a major in which they are able to excel, so academic skill as a residual also includes this and other factors that are associated with higher college achievement as measured by GPA, and must be interpreted as such. Our measure of "overachiever" status is Overachiever $=G P A-I Q$ by the intermediate factors that foster overachievement: academic skill and effort. Overachiever thus gives a measure of how well a student is performing academically relative to innate intelligence level as measured by our IQ test. We are aware that the use of percentile rankings may "flatten" the distribution of a variable, but feel that the benefits in establishing comparability among our dependent variables of interest outweigh this disadvantage for our purposes.

Moreover, we understand that each of these measures is imperfect, but at the same time capture fundamental phenomena that we seek to measure.

There are two main sets of implications from our model that we seek to test. The first is that parental actions toward the child are related to the innate attributes of the parent and the child. The second is how the academic behavior and achievement of college students is related to these parenting behaviors. In other words, does parental investment of time, energy, and encouragement toward children produce students who are "overachievers" who excel in college relative to their innate IQ? Conversely, we seek to ascertain the extent to which forms of parental "assistance" (such as higher allowances, helping children to cheat on tests, giving cars as gifts to children, etc.) produce children who become dependent "underachievers." Moreover, we would like to find out if parental time investments in children that produce overachieving children, such as reading to them, being involved with their schooling, or praising them for their accomplishments, operate through increased effort level or improved scholastic ability. 


\section{A. Ordinary Least Squares (OLS) Estimation}

We will examine these empirical relationships using several approaches. First is through the reducedform OLS estimation of the recursive equation

$$
y_{i}=\alpha_{i}+\boldsymbol{X}_{1}^{\prime} \boldsymbol{\beta}_{1}+\boldsymbol{X}_{2}^{\prime} \boldsymbol{\beta}_{2}+\varepsilon_{i}
$$

where $y_{i}$ is a dependent variable related to academic achievement, $\boldsymbol{X}_{1}$ is a vector of parenting characteristics, $\boldsymbol{X}_{2}$ is a vector of innate family and personal characteristics, $\boldsymbol{\beta}_{1}$ and $\boldsymbol{\beta}_{2}$ are parameter vectors, and $\varepsilon_{\mathrm{i}}$ is an error term. Although some of the variables in $\boldsymbol{X}_{1}$ are related to some of those in $\boldsymbol{X}_{2}$ (and even influenced by them as put forward by our theory), OLS estimation of the recursive equation will be unbiased and consistent given the absence of correlation between the error terms in (3) and $\boldsymbol{X}_{1}$ or $\boldsymbol{X}_{2}$. We are aware of the potential for omitted variable bias, and thus we attempted to include a large number of controls in both our survey and estimation, including parental behaviors, household background characteristics, age of student, number of siblings, and ethnicity.

Table 2 presents these results. ${ }^{7}$ We first examine student achievement (as measured by GPA percentile rank) with and without controls for IQ and effort. As we would be expect, GPA is strongly and positively associated with both IQ and effort, both significant at the $99 \%$ confidence level. Not controlling for other variables, there is a mildly negative correlation $(\rho=-0.069)$ between student effort and IQ, although both strongly and positively affect GPA. In our estimations on IQ, we find interesting associations between student IQ and parenting characteristics such as allowance level (negative), taking children to cultural events (positive), and rewards for academic effort (negative). Fathers are more involved with children who have a higher IQ, while mothers are more involved with children who have a lower IQ. Clearly we do not contend that these factors cause differences in IQ, but rather we view these estimations as conditional correlations.

Students who report that their parents praised them frequently when they were young (not just for academics), appear to exert a higher level of effort in college. This is consistent with Bénabou and Tirole (2000), who argue that if a principal can demonstrate confidence in the agent's ability, the agent will be more likely to exert effort in a given task. In this way a parent who regularly affirms his belief in a child will build 
the child's self-esteem and motivation. One would think the result may be subject to some simultaneity, in that a parent may praise the child more if they achieve more. However, we find parental praise to be almost perfectly orthogonal to IQ. Moreover, the question captures general praise, not merely for academics, and specifically asks for praise before college. The increased effort in college leads to a point estimate on overachieving that would suggest a 4.2 percentage point increase in effort, and is significant at a $99 \%$ level of confidence.

It is important to scrutinize such results for the possibility that they are driven by correlated unobservables. For example, suppose that some children, for whatever reason, consistently exert more effort than others and are then praised more by parents. While it is of course impossible to rule this out, we have both theoretical and empirical reasons to view it as unlikely. First, this possibility assumes that the child consistently exerts a sub-optimal level of effort for reasons unrelated to feedback from the parent, that is, chooses a level of effort that is incongruent with the rewards she expects to receive from that effort. Moreover, it would also assume that the parent is either not fully rational or not fully altruistic, because the parent under this scenario lavishes encouragement or assistance based on the child's effort rather than her welfare. Second, in our empirical explanation in columns 1 and 2 of Table 2 , the inclusion of effort in column 1 has a negligible affect on the encouragement and assistance variables--they are virtually identical in both estimations. Thus the encouragement/assistance variables are important to academic performance even after controlling for child effort.

These estimations also show that the frequency with which the parents read to their child has a positive, significant effect on GPA. But as Table 2 shows, reading to children appears to produce overachieving children not because it increases their effort (perhaps through higher self-esteem, according to our theory) as shown in Column 4, but because it augments their level of academic skill, as seen in Column 5.

Some variables such as higher levels of childhood allowance received and rewards given for academic effort display a negative relationship with GPA, through their negative association with a student's IQ rank (we use primary school allowance in the estimations and do not include secondary school allowance because of multicollinearity between the two variables; secondary school allowance shares a negative association with IQ 
and positive association to father's income). Of course such actions are unlikely to reduce a child's IQ, but they are consistent with the predictions of our model in that they are the kind of "assisting" actions a parent may take when lacking confidence in a child's own innate ability and motivation. However, as seen in Column 4, giving an allowance to a child in exchange for chores is associated with higher college academic effort (significant at an $88 \%$ level of confidence).

Our results provide other fuel for stereotypes about "spoiled kids." For example, on average, having received a car gift is negatively associated with lower college academic effort, and lower academic skill. This contributes to underachieving students. We find no statistical difference in IQ for children who received cars as gifts as compared to those who didn't, and since Overachiever percentile $=G P A$ percentile $-I Q$ percentile, the decreased effort causes these children to underachieve relative to their natural intelligence. Though the coefficients are statistically insignificant, Table 2 indicates students whose parents helped them cheat on an assignment before college exert less effort in college.

Psychological theory contends that an Apollonian/Promethean (intuitive) parent should be more likely to try to push the student to her potential, while a Dionysian/Epimethean (sensitive) parent should more likely accept the child for who she is. In contradiction to this theory, the results in Table 2 indicate parents whose attitudes are better described as "accepted who you are" seem to provoke a higher GPA rather than parents who "pushed you to reach your potential."

The results in Table 2 point to other relationships where causality is difficult to disentangle. The frequency of being taken to cultural events is associated with a higher student IQ (perhaps from a higher parental IQ), but is also associated with a lower college academic effort, thus also being heavily associated with underachievement. The older the student, the higher level of effort, but the lower the level of academic skill, possibly because older college students may be farther removed from skills learned in high school, but simultaneously more committed to their educational goals. The 66 Latino students and 35 African and African American students in the study score lower on the IQ test, but not significantly lower in GPA, rendering them overachievers on average by our measure. A similar phenomenon is found among those from families with a high number of siblings. Lastly, and perhaps most surprisingly, we find no statistically significant association for 
the direct effect of mother or father's education or income once we include parenting behaviors. The results we present are robust to alternative specifications, the inclusion of polynomials, and changes in functional form.

Many of the results of the reduced-form estimations appear more clearly in our OLS specification in Table 3, which estimates the components of student academic achievement solely on our significant parenting behaviors, removing the personal characteristics and parental characteristics (which are all independently insignificant) and insignificant parental behaviors. In this estimation effort and IQ are strongly related to student achievement. And though in the reduced-form estimation we remain wary of attributing causality, we clearly see the association of reading with enhanced academic skill and thus overachievement, parental praise being associated with increased academic effort, high allowances with low GPAs, and car gift and cultural events with lower college effort.

\section{B. Instrumental V ariables (IV) Estimation}

While the relationships we uncover in Table 2 yield unbiased estimates of family characteristics and parenting behaviors on the components of academic achievement, the very nature of their reduced form limits causal inference. We also seek to estimate our model more directly. Specifically, we posit that there exists a direct functional relationship $f$ between the ordered pair of types $\theta_{i} \times \theta_{j} \equiv T$ and the ordered pairs of Parent actions $n \times s \equiv A$, i.e. $f: T \rightarrow A$. These actions from the parent then create a belief by the Child about her type, i.e. $g: A \rightarrow \hat{\theta}$, where there is then a one-to-one correspondence between the Child's own action $e^{*}$ and $\hat{\theta}$. This set of structural relationships can be taken to the data.

Our strategy uses the set of pre-existing innate family and personal characteristics as first-stage exogenous instruments that determine parental behavior toward the child. Our second stage utilizes the estimated outcomes for parental behavior in turn as explanatory variables for child (student) academic behaviors and outcomes so that we estimate

$$
x_{1 j}=\boldsymbol{X}_{2}^{\prime} \lambda+\varepsilon_{1 i}
$$

for each parental behavior $j$, where $\lambda$ is a parameter vector of innate characteristics, and

$$
y_{i}=\hat{\boldsymbol{X}}_{1}^{\prime} \gamma+\tilde{\boldsymbol{X}}_{2}^{\prime} \psi+\varepsilon_{2 i}
$$


for each child response $i$ as a function of the vector of instrumented parental behaviors $\hat{\boldsymbol{X}}_{\mathbf{1}}$ and other exogenous characteristics in $\boldsymbol{X}_{2}, \tilde{\boldsymbol{X}}_{2}$, and where $\boldsymbol{\gamma}$ and $\boldsymbol{\psi}$ are also parameter vectors.

There are two concerns with this kind of IV estimation. The first issue relates to the strength of our instruments. Because in (4b) we are estimating a model with multiple endogenous right-hand side variables, a test of the partial F-statistics of joint significance of the excluded instruments in each model represents the first hurdle for testing instrument strength. As seen at the bottom of Table 4, the F-tests for joint significance of the excluded instruments indicate sufficient instrument strength for three of the four endogenous righthand-side variables that we include in the second stage estimation. ${ }^{8}$ However, because we have multiple endogenous variables in our model, we calculate Cragg-Donald statistics to test for weak identification with multiple endogenous regressors and Shea's partial $\mathrm{R}^{2}$ measures that test for intercorrelations among the instruments. If only a few of the instruments are doing all of the heavy lifting in each of the first-stage estimations, then functionally the estimation may be under-identified. Results of these joint tests of our instruments indicate weak-instrument problems in the IV models, even though many of our first-stage tests show statistical significance with multiple instruments. We attempt to ameliorate the problem through the use of limited information maximum likelihood (LIML) estimators that are more robust to weak instruments (Chao and Swanson, 2005; Hausman et al., 2005). The LIML point estimates and statistical significance are directionally similar to the two-stage least squares (2SLS) model, but tests for multiple endogenous variables continue to indicate some of our instruments may not be pulling their own weight in the first stage.

Despite some evidence of joint-instrument weakness in our 2SLS estimations, we believe these estimations are important because they represent the most direct estimation of our model. Furthermore, despite potential instrument weakness, we continue to find significant results in 2SLS estimations that corroborate some of our most basic OLS results. For this reason, we include the estimations with appropriate caveats.

The second potential issue with our IV estimates is that family and parental characteristics could display a direct effect on child behavior independent from their indirect association through parenting 
behavior and thus fail to satisfy the exclusion restriction requirement, necessary for an instrument to be valid (for example, research has shown a strong correlation between parental education and child achievement). Consistent with our model, however, we posit that the "effects" of these pre-existing characteristics, such as parental education, are manifest via identifiable parenting behaviors; once the behavior is accounted for, the pre-existing characteristics may lose explanatory power.

To address this second issue, we carry out Sargan exclusion restriction tests for each of our instruments (mother's and father's education and income, number of siblings, and Black, Latino, and Asian ethnicity). We carried out tests for each of our four dependent variables and all eight of our instruments. We find that in all of these 32 separate tests, none of these instruments adds significant explanatory power to the regression (even at an $80 \%$ level of confidence) when they are subtracted from the list of instruments and added to the second stage estimations in (4b). In other words, at least within the scope of our data, exogenous family characteristics appear to affect children through parental behaviors, but not directly on their own. For example, the fact that a parent may be Asian affects a child through an identifiable behavior that is correlated with being Asian, but there is no direct effect on the child's behavior by simply coming from an Asian family. That these instruments are determined prior to the parenting behaviors moreover gives us a theoretical basis for their exogeneity. However, though it is widely used, the Sargan test assumes the validity of a subset of instruments in the testing of a given instrument. And for this reason, it does not necessarily present a surefire test for the exclusion restriction. With these caveats to our instrumental variables estimations, we proceed.

We report estimations nearly identical to our instrumental first-stage estimations of (4a) in Table 4; however, in Table 4 we also include IQ rank as an additional explanatory variable. From these linear estimations of the function $f$, it is clear that parental behavior is responsive to both child type as well as parental characteristics, justifying their use as instruments. Whether a student was praised frequently, taken to cultural events, and read to frequently as a child are all positively related to mother's and father's education, but negatively related to the number of siblings in the student's family as well as to Asian family background, with nearly all of these relationships significant at the $99 \%$ level of confidence. Students from Latino families are also less likely 
to have had parents that read to them, but are not less likely to be praised. Frequency of parental criticism is negatively related to student IQ, father's income, and positively related to Asian family background.

Parental characteristics also influence pecuniary transfers to children. The amount of allowance a student was given and the likelihood receiving a car as a gift from parents are both (not surprisingly) increasing functions of father's income. That a child's allowance was conditional upon carrying out chores is associated with lower parental incomes, but higher levels of parental education, especially of the mother. Students from Asian families were more likely to be given financial rewards for effort put into school, but less likely to be given an allowance that was contingent upon fulfilling chores at home.

Consistent with our model, these pecuniary transfers between parents and children also seem to be affected by child type, specifically by their IQ. First, our results reveal that students who scored lower on the IQ test were given higher allowances as children, a relationship significant at the $99 \%$ confidence level. Furthermore, students with lower IQ scores were more likely to have been rewarded with money for putting effort into schoolwork ( $90 \%$ confidence), consistent with the theory of Bénabou and Tirole (2003). Low IQ students were also more likely to have been given a car by their parents, although the latter relationship is significant only at the $76 \%$ level. One possible alternative explanation for this is correlation between the IQ of parents and children. For example, a parent with a high IQ may have had an easier time academically, thus expect effort in school, rather than giving rewards for it. But it is hard to understand how low parental IQ should necessarily result in parents being more forthright with monetary gifts to children. Moreover, in each of these estimations we control for mother's and father's education, finding that (controlling for income) more educated fathers offer lower allowances.

Our second-stage estimations in Table 5 indicate academic behavior in college is related in important ways to parenting behaviors, though statistical significance is weaker in most cases than in the reduced-form estimations in Table 2 (perhaps a reflection of weak-instrument problems previously discussed). We include in the 2SLS estimations a subset of our parenting variables based on the strength of the (first-stage) exogenous parent and family characteristics as instruments. In this second stage, IQ and effort are clearly major components of academic achievement. A 10-percentile-point increase in IQ rank is associated with an 
increase of 1.9 percentile points in GPA rank. A 10-percentile-point increase in effort rank (based on percentile point estimates on a self-reported effort scale) is associated with a 3.5 percentile point increase in GPA rank. Being read to as a child by parents is associated with a 19.7 percentile point increase in GPA rank, via increased academic skill. Conversely, receiving a car as a gift is associated with a 28.3 percentile point decrease in effort. The significance of parental praise, however, disappears in our second-stage estimations.

While in Table 5 we estimate each equation separately using two-stage least squares, the dependent variables may be sufficiently interrelated that they are subject to correlations in their respective error terms. Thus in Table 6 we carry out our estimation using three-stage least squares, jointly estimating the equations in (4a) and (4b), which given cross-correlation in error terms may yield increased estimation efficiency. (We are forced to drop "overachiever" as a dependent variable in the joint estimations since its relationship to GPA percentile yields a singular covariance matrix among the error terms). The 3SLS estimations indeed yield stronger effects of IQ and scholastic effort on student GPA, with point estimates implying that a 10percentile-point increase in IQ rank (effort rank) is associated with a 6.8 (13.7) percentile point increase in GPA rank. Like the 2SLS and reduced-form estimates, parental reading is associated with a boost in GPA rank through increased academic skill (significant at the 95th percentile). As in the 2SLS estimations, parental praise carries a positive sign on academic effort in our 3SLS estimations, but unlike the OLS estimations, is statistically insignificant. Point estimates of the other parenting variables in the jointly estimated 3SLS estimations parallel closely to those in the 2SLS estimations.

One potential source of bias that could affect all of these estimations is the issue of household selection into college. A large number of studies (see for example Black and Sufi, 2002) have documented the positive relationship between college enrollment and socio-economic status (SES). In particular, college enrollment is more likely among children with high levels of mother and father education and income. The direction of possible bias in our estimations resides in the extent to which parental behaviors are correlated with SES, and the extent to which SES affects self-selection into our college sample.

To ascertain the direction of possible bias, we carried out OLS estimations of these key SES variables on our parental behavior variables (estimations not presented here, but are available on the web). We find 
father's income to be significantly and positively associated with child attendance at cultural events, buying a car for a teenage child, the amount of a weekly allowance, and a father pushing a child to reach her maximum potential, but negatively associated with praise for the child. Not surprisingly, mother's income is positively associated with cultural events and the mother pushing a child to reach maximum potential. Both mother and father's education is strongly associated with reading to children and cultural events. Thus it appears from our data that high SES parents are likely to push their children into college as a means of increasing their potential, children who might not have entered college otherwise.

High SES selection into college may therefore cause us to underestimate of the effects of reading to children on college performance, and overestimate the negative association between both high allowances and purchasing a car for a teenager and college achievement (since college selection may be responsible for the association alongside its negative effect on self-esteem). It also may bias downwards our estimate of the effect of parental praise on college effort since children from wealthier families appear to receive less praise, but are more likely to enter college. Missing from college are less wealthy children who were praised more and would have performed better academically as a result, but lacked the parental drive to push them into college.

\section{SUMMARY AND CONCLUSIONS}

This paper presents a model in which altruistic parents have better information about the innate ability of their children than the children do themselves. Because effort is complementary to the child's innate ability, but is also costly, parents will treat children of varying abilities differently, having an incentive to directly provide for children with lower innate ability, while encouraging greater effort among those of high ability. A parent's own characteristics also influence his behavior toward a child. Thus a child's self-esteem is a product of the signals sent by parental behaviors towards her that are partly determined by her own innate giftedness and partly determined by the characteristics of her parents. This in turn influences the effort with which she applies herself to a task, such as education. Consequently, our model views parental behavior as a function of exogenous attributes of children and parents, and the behavior of children as a function of their innate ability and the actions of their parents toward them in childhood. 
Testing these hypotheses using data from a survey and IQ test of 651 university students, we find supporting evidence in both reduced-form and instrumental variables estimations of our model. A summary of our results suggest that both parental and family characteristics, such as income, ethnic background, education, and family size play significant roles in the behavior of parents toward children, particularly in the time and effort they spend praising them for their accomplishments and reading to them, setting their allowance, and buying them gifts. These behaviors also appear to be influenced by the innate ability of the child. Our results show that parents of students with relatively lower IQ scores were more likely to give them larger allowances and financial rewards for academic effort.

These parental actions towards children appear to affect their work habits and performance even into college. Students who were praised frequently by their parents as children exhibit a greater level of effort in college academic work, rendering them overachievers in some of our specifications. Students who were given large allowances and cars exhibit lower levels of effort on average, and in some specifications, also exhibit lower levels of academic achievement and underachieve relative to their potential. Students who were frequently read to by their parents tend to be academic overachievers, mainly through an increase in intangible academic skill.

It is important to interpret our findings in light of the proxy variables we chose to represent both parental and child attributes and our parental behaviors. For example, we would not contend that it is buying a car for a child per se that causes lackadaisical effort, but rather a style of parenting, communicated by myriad overt and unspoken actions of the parent which may be correlated with a particular action that we measure. A good deal of behavior, particularly family behavior, is endogenous to other coexisting behaviors; however the nature of our model and data allows us to draw out these behaviors beginning from innate family characteristics, which we would argue are largely predetermined. In this respect, we think that these findings add to our understanding of under- and overachievement by college students, as well as the causes and consequences of different approaches to parenting. 


\section{ACKNOWLEDGEMENTS}

The authors wish to thank Michael Jonas, Tee Kilenthong, John Veitch, Romain Wacziarg, and two referees for

helpful comments, along with the students who participated in the survey that was key to our empirical work.

${ }^{1}$ We will continue to refer to the latter player as the Parent, although in a more general version of the model, this player might more generally represent the significant influences in the decision-making of the Child within her social environment, such as a teacher, coach, or even peer group. We will use capitals when referring to Child and Parent as players in our model, but lower-case letters when referring to a parent or child more generally.

${ }^{2}$ A more general assumption is made by Bénabou and Tirole (2000), who assume a density function $f(\theta)$ with distribution $F(\theta)$ that is common knowledge between the players of the game and that the Child receives a signal $\sigma$ which is indicative of $\theta_{i}$, in the sense that for some $\sigma_{1}>\sigma_{2}, E\left[\theta_{i} \mid \sigma_{1}\right]>E\left[\theta_{i} \mid \sigma_{2}\right]$, and that the ratio of the conditional densities $g\left(\sigma \mid \theta_{H}\right) / g\left(\sigma \mid \theta_{L}\right)$ is increasing in $\theta_{i}$.

${ }^{3}$ Full problem-solving test and survey available upon request.

${ }^{4}$ In the survey, $66.3 \%$ of the students believed that they were " $a$ little more intelligent than their peers" while $8.8 \%$ maintained that they were "much more intelligent than their peers". However, $52.2 \%$ reported that their parents believed them to be "a little more intelligent than their peers" while $35.3 \%$ reported that their parents believed them to be "much more intelligent than their peers."

${ }^{5}$ Calculated as $100(n$-rank) $/ n$. While the rank-percentile may artificially flatten the distribution, due to bunching of GPA's and test scores, the percentile of absolute scores provided a skewed distribution. Results were virtually identical in both cases and so rank percentile was used for ease of interpretation.

${ }^{6}$ The regression estimated in calculating the Academic Skill residual is GPA $=20.02=0.171 I Q+0.308$ Effort. T-statistics on all coefficients in the regression are 4.49, 4.38, and 6.04, respectively, all significant at the $99 \%$ level of confidence.

${ }^{7}$ Because of the large number of variables we estimate in Table 2, we drop a substantial number of observations when a single question remained unanswered in a survey. We carried out a series of estimations that correct for missing observations that permit estimation on nearly the full sample size. We do not include these, however, since our estimations using missing observation techniques do not differ significantly from those in Table 2.

${ }^{8}$ According to Stock et al. (2002) the first-stage F-statistic should typically exceed 10 for two stage least squares to be reliable in a regression with one endogenous variable. The authors list first-stage F-statistic critical values for weak instrument tests for 2SLS with 5 to 10 instruments allowing for a maximum relative bias of $10 \%$ compared to OLS, and at the 5\% significance level, as between 10.83 and 11.49 . 


\section{REFERENCES}

America’s Best Colleges 2008. U.S. News \& World Report. Available http://www.usnews.com/ usnews/edu/college/rankings/rankindex.php.

ANDERSON, T.W. (1984). Introduction to Multivariate Statistical Analysis. New York: Wiley.

BÉNABOU, R. and TIROLE, J. (2003). Intrinsic and Extrinsic Motivation. Review of Economic Studies, 70, 489-520.

and --------. (2000). Self-Confidence and Social Interactions. NBER Working Paper 7585.

BLACK, S.E., DEVEREUX, P.J. and SALVANES, K.G. (2005). Why the Apple Doesn't Fall Far: Understanding the Intergenerational Transmission of Human Capital. American Economic Review, 95(1), 437-9.

CHAO, J.C and SWANSON, N. R. (2005). Consistent Estimation with a Large Number of Weak Instruments. Econometrica, 73(5), 1673-92.

CONDRY, J. and CHAMBERS, J. (1978). Intrinsic Motivation and the Process of Learning. in M. Lepper and D. Greene (eds.), The Hidden Cost of Rewards: New Perspectives on the Psychology of Human Motivation. New York: John Wiley.

COOLEY, C. H. (1902). Human Nature and Social Order. New York: Scribner's, 179-85.

DECI, E.L. (1971). Effects of Externally Mediated Rewards on Intrinsic Motivation. Journal of Personality \& Social Psychology, 18(1), 105-15.

FRYER, R. and LEVITT, S. (2006). The Black-White Test Score Gap through Third Grade. American Law and Economics Review, 8(2), 249-81. and -------- (2004). Understanding the Black-White Test Score Gap in the First Two Years of School. Review of Economics and Statistics, 86(2), 447-64.

GECAS, V. and SCHALBE, M. (1986). Parental Behavior and Adult Self-Esteem. Journal of Marriage and the Family, 48(1), 37-46.

HAUSMAN, J., STOCK, J.H., and YOGO, M. (2005). Asymptotic Properties of the Hahn-Hausman test for Weak-Instruments. Economics Letters, 89, 333-42.

HAVEMAN, R. and WOLFE, B. (1995). The Determinants of Children's Attainments: A Review of Methods and Findings. Journal of Economic Literature, 33(4), 1829-78.

HENDERLONG, J. and LEPPER, M.R. (2002). The Effects of Praise on Children's Intrinsic Motivation: A Review and Synthesis. Psychological Bulletin, 128(5), 774-95. 
JUNG, C. (1920). Psychological Types, Baynes, H.G. (translator). Re-published, 1971. Bollingen Series, Princeton: Princeton University Press

KEIRSEY, D. and BATES, M. (1984). Please Understand Me: Character and Temperament Types. Del Mar, California: Gnosology Books Ltd.

KREMER, M., MIGUEL, E. and THORNTON, R. (2004). Incentives to Learn. National Bureau of Economic Research, Working Paper \#10971.

KREPS, D.M. (1997). Intrinsic Motivation and Extrinsic Incentives. The American Economic Review, 87(2), 359-64.

LEMBERT, M. (1985). The Impact of Mothers Beliefs, Expectations, and Attributions on Children's Primary School Dropout: A Study of Low Socioeconomic Status Families in Urban Mexico. Stanford University Ph.D. dissertation.

LEPPER, M.R., GREENE, D. and NISBETT, R.E. (1973). Undermining Children's Intrinsic Interest with Extrinsic Reward: A Test of the "Overjustification” Hypothesis. Journal of Personality \& Social Psychology, 28(1), 129-37.

MUELLER, C. and DWECK, C. (1998). Praise for Intellegence Can Undermine Children's Motivation and Performance. Journal of Personality and Social Pycology, 5(1), 33-52.

OREOPOLOUS, P., PAGE, M.E., and STEVENS, A.H. (2006). Does Human Capital Transfer from Parent to Child? The Intergenerational Effects of Compulsory Schooling. Journal of Labor Economics, 24(4), 729-60.

SARGAN, J.D. (1958). The Instability of the Leontief Dynamic Model. Econometrica, 26, 381-92.

SHEA, J. (1997). Instrument Relevance in Multivariate Linear Models: A Simple Measure. Review of Economics and Statistics, 79, 348-52.

SPENCE, M. (1974). Market Signaling: Informational Transfer in Hiring and Related Screening Processes. Cambridge: Harvard University Press.

STOCK, J.H., WRIGHT, J.H., and YOGO, M. (2002). A Survey of Weak Instruments and Weak Identification in Generalized Method of Moments. Journal of Business \& Economic Statistics, 20(4), 518-29. 


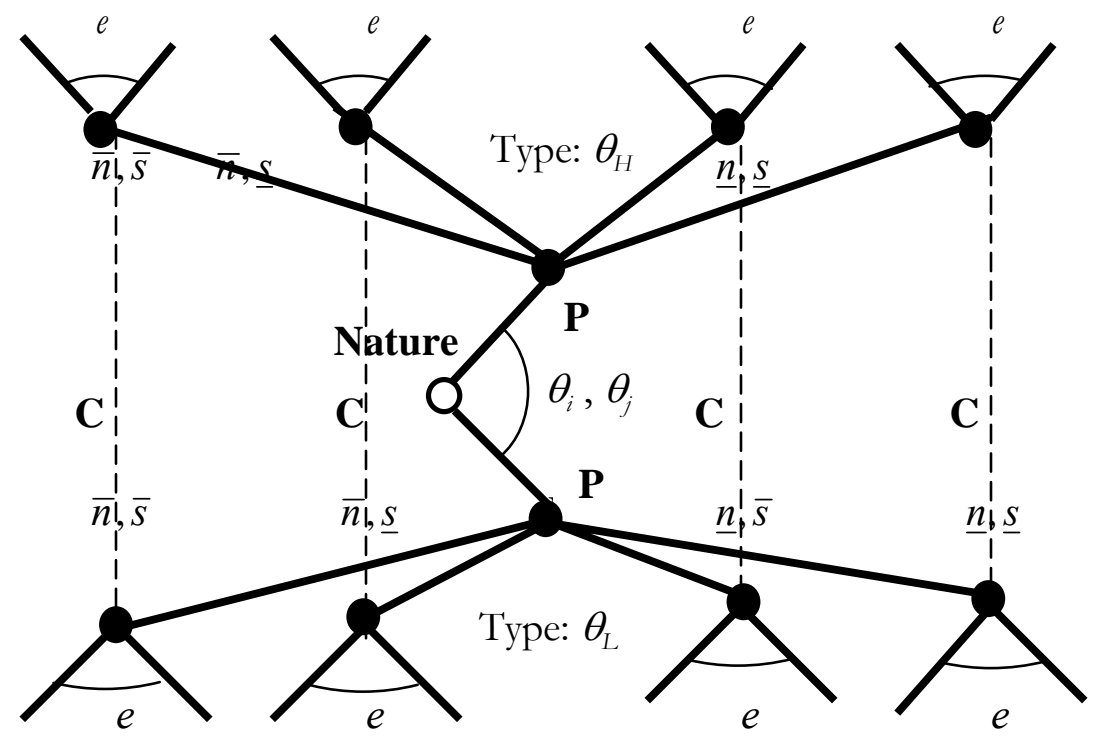

Figure 1: The Parent-Child Game 


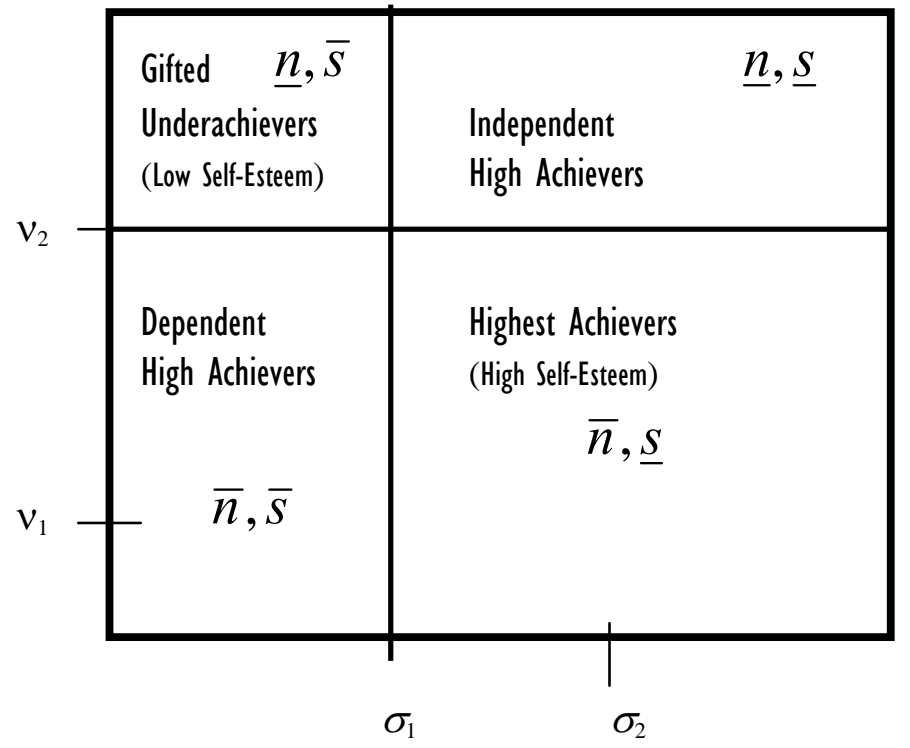

Figure 2A: Mapping for $\theta_{H}$

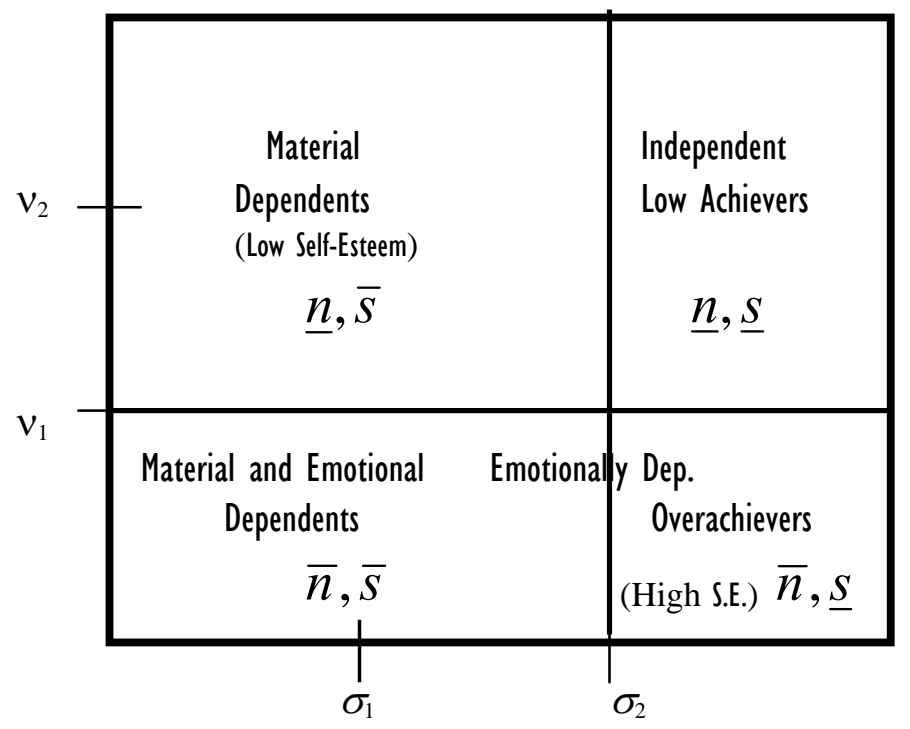

Figure 2B: Mapping for $\theta_{L}$ 
Table 1: Summary Statistics

\begin{tabular}{|c|c|c|}
\hline & Mean & $\begin{array}{l}\text { Standard } \\
\text { Deviation }\end{array}$ \\
\hline GPA Percentile & 49.91 & 28.89 \\
\hline IQ Percentile & 49.92 & 28.88 \\
\hline Level of Academic Effort & 57.58 & 24.70 \\
\hline Academic Skill & 49.92 & 28.88 \\
\hline Mother was involved $(1=$ yes, $0=$ no $)$ & 0.92 & 0.28 \\
\hline Father was involved $(1=$ yes, $0=$ no $)$ & 0.73 & 0.44 \\
\hline Frequency of parental praise (4 high--1 low) & 2.89 & 0.94 \\
\hline Frequency of parent reading to child (4 high--1 low) & 2.78 & 1.08 \\
\hline Frequency of going to cultural event ( 4 high--1 low) & 2.51 & 0.98 \\
\hline Frequency of parental criticism (4 high--1 low) & 1.90 & 0.89 \\
\hline $\begin{array}{l}\text { Frequency of parents blaming other factors } \\
(4=\text { frequently }-1=\text { infrequently) }\end{array}$ & 1.51 & 0.80 \\
\hline Parents helped student cheat $(1=$ yes, $0=$ no $)$ & 0.06 & 0.24 \\
\hline Avg. allowance received in primary school (\$) & 6.13 & 17.80 \\
\hline Allowance for completing task $(1=$ yes, $0=$ no $)$ & 0.38 & 0.54 \\
\hline Reward for academic effort $(1=$ yes, $0=$ no $)$ & 0.21 & 0.41 \\
\hline Parents gave car as gift $(1=$ yes, $0=$ no $)$ & 0.38 & 0.51 \\
\hline $\begin{array}{l}\text { Mother "accepted son/daughter for who s/he was" }(=1) \\
\text { Mother "pushed son/daughter to reach potential" }(=2)\end{array}$ & 1.48 & 0.50 \\
\hline $\begin{array}{l}\text { Father "accepted son/daughter for who s/he was" }(=1) \\
\text { Father "pushed son/daughter to reach potential" (=2) }\end{array}$ & 1.47 & 0.50 \\
\hline Father Annual Income & 3.97 & 1.56 \\
\hline Mother Annual Income & 2.89 & 1.47 \\
\hline $\begin{array}{l}\text { Father Education }(1=\text { less than high school; } 2=\text { high } \\
\text { school; } 3=\text { college; } 4=\text { graduate school })\end{array}$ & 2.92 & 0.93 \\
\hline $\begin{array}{l}\text { Mother Education }(1=\text { less than high school; } 2=\text { high } \\
\text { school; } 3=\text { college; } 4=\text { graduate school })\end{array}$ & 2.75 & 0.87 \\
\hline Average \# of siblings & 1.73 & 1.49 \\
\hline Age (years) & 21.37 & 3.82 \\
\hline Asian $(1=$ yes, $0=$ no $)$ & 0.33 & 0.47 \\
\hline Black $(1=$ yes, $0=$ no $)$ & 0.05 & 0.23 \\
\hline Latino $(1=$ yes, $0=$ no $)$ & 0.10 & 0.30 \\
\hline Observations & 651 & \\
\hline
\end{tabular}

Note: Income brackets: $1=$ Did not work/Not a part of household; $2=<\$ 25,000$ to $\$ 50,000 ; 3=\$ 25,000$ to $\$ 50,000 ; 4=\$ 50,000$ to $\$ 100,000 ; 5=\$ 100,001$ to $\$ 200,000 ; 6=\$ 200,001$ to $\$ 500,000 ; 7=>\$ 500,000$. 
Table 2: OLS Reduced-Form Estimates

\begin{tabular}{|c|c|c|c|c|c|c|}
\hline & $(1)$ & $(2)$ & (3) & (4) & $(5)$ & $(6)=(2)-(3)$ \\
\hline & $\begin{array}{c}\text { GPA } \\
\text { Percentile }\end{array}$ & $\begin{array}{c}\text { GPA } \\
\text { Percentile }\end{array}$ & $\begin{array}{c}\text { IQ } \\
\text { Percentile }\end{array}$ & $\begin{array}{c}\text { Level of } \\
\text { Acad. } \\
\text { Effort }\end{array}$ & $\begin{array}{c}\text { Academic } \\
\text { Skill }\end{array}$ & Overachiever \\
\hline IQ Percentile & $\begin{array}{l}0.159^{* * *} \\
(0.047)\end{array}$ & & & & & \\
\hline Level of Academic Effort & $\begin{array}{l}0.291 * * * \\
(0.061)\end{array}$ & & & & & \\
\hline Mother was involved & $\begin{array}{l}1.029 \\
(5.506)\end{array}$ & $\begin{array}{l}0.951 \\
(5.666)\end{array}$ & $\begin{array}{l}-10.212^{*} \\
(5.490)\end{array}$ & $\begin{array}{l}4.826 \\
(4.205)\end{array}$ & $\begin{array}{l}0.657 \\
(5.704)\end{array}$ & $\begin{array}{l}11.848 \\
(7.427)\end{array}$ \\
\hline Father was involved & $\begin{array}{l}-0.618 \\
(3.295)\end{array}$ & $\begin{array}{l}-1.238 \\
(3.379)\end{array}$ & $\begin{array}{l}5.416^{*} \\
(3.266)\end{array}$ & $\begin{array}{l}-5.355^{* *} \\
(2.503)\end{array}$ & $\begin{array}{l}-0.266 \\
(3.403)\end{array}$ & $\begin{array}{l}-7.245 \\
(4.429)\end{array}$ \\
\hline Frequency of parental praise & $\begin{array}{l}1.117 \\
(1.698)\end{array}$ & $\begin{array}{l}2.048 \\
(1.739)\end{array}$ & $\begin{array}{l}-1.033 \\
(1.698)\end{array}$ & $\begin{array}{l}4.199 * * * \\
(1.301)\end{array}$ & $\begin{array}{l}1.215 \\
(1.751)\end{array}$ & $\begin{array}{l}3.223 \\
(2.279)\end{array}$ \\
\hline Freq of parents read to child & $\begin{array}{l}5.120^{* * *} \\
(1.622)\end{array}$ & $\begin{array}{l}4.964 * * * \\
(1.668)\end{array}$ & $\begin{array}{l}-2.926^{*} \\
(1.636)\end{array}$ & $\begin{array}{l}0.248 \\
(1.256)\end{array}$ & $\begin{array}{l}5.543 * * * \\
(1.684)\end{array}$ & $\begin{array}{l}\text { 7.934*** } \\
(2.186)\end{array}$ \\
\hline Freq of cultural events & $\begin{array}{l}0.126 \\
(1.641)\end{array}$ & $\begin{array}{l}-0.434 \\
(1.678)\end{array}$ & $\begin{array}{l}2.876^{*} \\
(1.627)\end{array}$ & $\begin{array}{l}-3.428^{* * *} \\
(1.247)\end{array}$ & $\begin{array}{l}-0.019 \\
(1.690)\end{array}$ & $\begin{array}{l}-3.286 \\
(2.199)\end{array}$ \\
\hline Freq of parental criticism & $\begin{array}{l}0.480 \\
(1.734)\end{array}$ & $\begin{array}{l}0.538 \\
(1.792)\end{array}$ & $\begin{array}{l}-0.456 \\
(1.746)\end{array}$ & $\begin{array}{l}0.684 \\
(1.339)\end{array}$ & $\begin{array}{l}0.576 \\
(1.806)\end{array}$ & $\begin{array}{l}1.303 \\
(2.349)\end{array}$ \\
\hline Freq of blaming other factors & $\begin{array}{l}0.007 \\
(1.968)\end{array}$ & $\begin{array}{l}-0.046 \\
(2.016)\end{array}$ & $\begin{array}{l}-5.565^{* * *} \\
(1.983)\end{array}$ & $\begin{array}{l}2.246 \\
(1.519)\end{array}$ & $\begin{array}{l}0.138 \\
(2.030)\end{array}$ & $\begin{array}{l}5.057^{*} \\
(2.643)\end{array}$ \\
\hline Parents helped student cheat & $\begin{array}{l}-1.419 \\
(5.634)\end{array}$ & $\begin{array}{l}-1.943 \\
(5.819)\end{array}$ & $\begin{array}{l}4.999 \\
(5.800)\end{array}$ & $\begin{array}{l}-4.354 \\
(4.443)\end{array}$ & $\begin{array}{l}-1.651 \\
(5.859)\end{array}$ & $\begin{array}{l}-7.411 \\
(7.628)\end{array}$ \\
\hline Allowance primary school (\$) & $\begin{array}{l}-0.132^{*} \\
(0.068)\end{array}$ & $\begin{array}{l}-0.156^{* *} \\
(0.070)\end{array}$ & $\begin{array}{l}-0.171^{* *} \\
(0.070)\end{array}$ & $\begin{array}{l}0.015 \\
(0.053)\end{array}$ & $\begin{array}{l}-0.137^{*} \\
(0.071)\end{array}$ & $\begin{array}{l}-0.002 \\
(0.092)\end{array}$ \\
\hline Allowance for task only & $\begin{array}{l}0.574 \\
(2.860)\end{array}$ & $\begin{array}{l}1.486 \\
(2.950)\end{array}$ & $\begin{array}{l}1.307 \\
(2.858)\end{array}$ & $\begin{array}{l}3.368 \\
(2.191)\end{array}$ & $\begin{array}{l}0.547 \\
(2.974)\end{array}$ & $\begin{array}{l}0.098 \\
(3.868)\end{array}$ \\
\hline Reward for academic effort & $\begin{array}{l}0.896 \\
(3.329)\end{array}$ & $\begin{array}{l}0.062 \\
(3.424)\end{array}$ & $\begin{array}{l}-7.520^{* *} \\
(3.359)\end{array}$ & $\begin{array}{l}1.999 \\
(2.573)\end{array}$ & $\begin{array}{l}1.266 \\
(3.448)\end{array}$ & $\begin{array}{l}7.764 * \\
(4.488)\end{array}$ \\
\hline Received a car as gift & $\begin{array}{l}-7.443^{* *} \\
(2.877)\end{array}$ & $\begin{array}{l}-8.885^{* * *} \\
(2.962)\end{array}$ & $\begin{array}{l}0.082 \\
(2.855)\end{array}$ & $\begin{array}{l}-5.063^{* *} \\
(2.189)\end{array}$ & $\begin{array}{l}-7.759 * * * \\
(2.986)\end{array}$ & $\begin{array}{l}-8.761 * * \\
(3.883)\end{array}$ \\
\hline Mother pushed to potential & $\begin{array}{l}-5.064^{*} \\
(2.760)\end{array}$ & $\begin{array}{l}-4.383 \\
(2.848)\end{array}$ & $\begin{array}{l}2.514 \\
(2.763)\end{array}$ & $\begin{array}{l}1.829 \\
(2.119)\end{array}$ & $\begin{array}{l}-4.986^{*} \\
(2.870)\end{array}$ & $\begin{array}{l}-7.873^{* *} \\
(3.733)\end{array}$ \\
\hline Father pushed to potential & $\begin{array}{l}-6.389 * * \\
(2.725)\end{array}$ & $\begin{array}{l}-7.092 * * \\
(2.806)\end{array}$ & $\begin{array}{l}-4.426 \\
(2.739)\end{array}$ & $\begin{array}{l}-0.855 \\
(2.101)\end{array}$ & $\begin{array}{l}-6.548^{* *} \\
(2.830)\end{array}$ & $\begin{array}{l}-2.326 \\
(3.678)\end{array}$ \\
\hline Father Annual Income & $\begin{array}{l}1.843^{*} \\
(1.002)\end{array}$ & $\begin{array}{l}1.970^{*} \\
(1.037)\end{array}$ & $\begin{array}{l}0.129 \\
(1.023)\end{array}$ & $\begin{array}{l}0.410 \\
(0.783)\end{array}$ & $\begin{array}{l}1.913^{*} \\
(1.044)\end{array}$ & $\begin{array}{l}1.718 \\
(1.359)\end{array}$ \\
\hline Mother Annual Income & $\begin{array}{l}0.263 \\
(0.931)\end{array}$ & $\begin{array}{l}0.155 \\
(0.960)\end{array}$ & $\begin{array}{l}-1.702^{*} \\
(0.946)\end{array}$ & $\begin{array}{l}0.420 \\
(0.725)\end{array}$ & $\begin{array}{l}0.384 \\
(0.966)\end{array}$ & $\begin{array}{l}1.893 \\
(1.258)\end{array}$ \\
\hline Father Education & $\begin{array}{l}0.178 \\
(1.711)\end{array}$ & $\begin{array}{l}0.487 \\
(1.769)\end{array}$ & $\begin{array}{l}0.467 \\
(1.744)\end{array}$ & $\begin{array}{l}1.145 \\
(1.336)\end{array}$ & $\begin{array}{l}-0.004 \\
(1.782)\end{array}$ & $\begin{array}{l}-0.089 \\
(2.319)\end{array}$ \\
\hline Mother Education & $\begin{array}{l}1.328 \\
(1.985)\end{array}$ & $\begin{array}{l}1.496 \\
(2.054)\end{array}$ & $\begin{array}{l}1.433 \\
(1.994)\end{array}$ & $\begin{array}{l}-0.196 \\
(1.527)\end{array}$ & $\begin{array}{l}1.467 \\
(2.069)\end{array}$ & $\begin{array}{l}0.901 \\
(2.693)\end{array}$ \\
\hline Number of siblings & $\begin{array}{l}0.345 \\
(1.000)\end{array}$ & $\begin{array}{l}0.119 \\
(1.027)\end{array}$ & $\begin{array}{l}-2.492^{* *} \\
(1.017)\end{array}$ & $\begin{array}{l}0.453 \\
(0.779)\end{array}$ & $\begin{array}{l}0.405 \\
(1.034)\end{array}$ & $\begin{array}{l}2.760^{* *} \\
(1.346)\end{array}$ \\
\hline Age in years & $\begin{array}{l}-0.145 \\
(0.343)\end{array}$ & $\begin{array}{l}0.141 \\
(0.350)\end{array}$ & $\begin{array}{l}-0.123 \\
(0.343)\end{array}$ & $\begin{array}{l}0.877^{* * *} \\
(0.264)\end{array}$ & $\begin{array}{l}-0.067 \\
(0.354)\end{array}$ & $\begin{array}{l}0.092 \\
(0.458)\end{array}$ \\
\hline Asian & $\begin{array}{l}-3.179 \\
(3.352)\end{array}$ & $\begin{array}{l}-2.385 \\
(3.461)\end{array}$ & $\begin{array}{l}-1.227 \\
(3.407)\end{array}$ & $\begin{array}{l}2.267 \\
(2.612)\end{array}$ & $\begin{array}{l}-3.103 \\
(3.489)\end{array}$ & $\begin{array}{l}-1.076 \\
(4.537)\end{array}$ \\
\hline Black & $\begin{array}{l}-4.268 \\
(6.318)\end{array}$ & $\begin{array}{l}-7.381 \\
(6.419)\end{array}$ & $\begin{array}{l}-25.886^{* * *} \\
(6.397)\end{array}$ & $\begin{array}{l}3.472 \\
(4.900)\end{array}$ & $\begin{array}{l}-4.382 \\
(6.464)\end{array}$ & $\begin{array}{l}18.087 * * \\
(8.415)\end{array}$ \\
\hline Latino & $\begin{array}{l}-1.178 \\
(4.878)\end{array}$ & $\begin{array}{l}-1.006 \\
(4.983)\end{array}$ & $\begin{array}{l}-6.195 \\
(4.674)\end{array}$ & $\begin{array}{l}0.751 \\
(3.616)\end{array}$ & $\begin{array}{l}-1.171 \\
(5.071)\end{array}$ & $\begin{array}{l}6.357 \\
(6.531)\end{array}$ \\
\hline Constant & $\begin{array}{l}2.294 \\
(13.527)\end{array}$ & $\begin{array}{l}23.643^{*} \\
(13.188)\end{array}$ & $\begin{array}{l}81.956^{* * *} \\
(12.852)\end{array}$ & $\begin{array}{l}33.563 * * * \\
(9.873)\end{array}$ & $\begin{array}{l}26.737 * * \\
(13.322)\end{array}$ & $\begin{array}{l}-56.444 * * * \\
(17.288)\end{array}$ \\
\hline Observations & 443 & 444 & 469 & 468 & 443 & 444 \\
\hline R-squared & 0.19 & 0.13 & 0.14 & 0.10 & 0.12 & 0.12 \\
\hline
\end{tabular}


Table 3: OLS Estimates - Student Achievements and Parental Behaviors

\begin{tabular}{|c|c|c|c|c|c|}
\hline & (1) & $(2)$ & (3) & (4) & (5) \\
\hline & GPA Percentile & GPA Percentile & $\begin{array}{c}\text { Level of Acad. } \\
\text { Effort }\end{array}$ & Academic Skill & Overachiever \\
\hline IQ Percentile & $\begin{array}{l}0.161 * * * \\
(0.040)\end{array}$ & & & & \\
\hline Level of Academic Effort & $\begin{array}{l}0.261^{* * *} \\
(0.047)\end{array}$ & & & & \\
\hline Freq read to child & $\begin{array}{l}5.659 * * * \\
(1.281)\end{array}$ & $\begin{array}{l}5.351 * * * \\
(1.326)\end{array}$ & $\begin{array}{l}-1.655 \\
(1.128)\end{array}$ & $\begin{array}{l}5.917 * * * \\
(1.330)\end{array}$ & $\begin{array}{l}5.573 * * * \\
(1.750)\end{array}$ \\
\hline Freq parental praise & $\begin{array}{l}0.496 \\
(1.398)\end{array}$ & $\begin{array}{l}1.413 \\
(1.436)\end{array}$ & $\begin{array}{l}4.452 * * * \\
(1.215)\end{array}$ & $\begin{array}{l}0.530 \\
(1.439)\end{array}$ & $\begin{array}{l}2.380 \\
(1.895)\end{array}$ \\
\hline Received a car as gift & $\begin{array}{l}-4.386^{*} \\
(2.421)\end{array}$ & $\begin{array}{l}-5.438^{* *} \\
(2.503)\end{array}$ & $\begin{array}{l}-4.382^{* *} \\
(2.096)\end{array}$ & $\begin{array}{l}-4.531 * \\
(2.510)\end{array}$ & $\begin{array}{l}-5.016 \\
(3.302)\end{array}$ \\
\hline Allowance (\$) & $\begin{array}{l}-0.141^{* *} \\
(0.063)\end{array}$ & $\begin{array}{l}-0.172 * * * \\
(0.065)\end{array}$ & $\begin{array}{l}0.011 \\
(0.056)\end{array}$ & $\begin{array}{l}-0.145^{* *} \\
(0.065)\end{array}$ & $\begin{array}{l}0.020 \\
(0.086)\end{array}$ \\
\hline Freq of cultural events & $\begin{array}{l}1.062 \\
(1.342)\end{array}$ & $\begin{array}{l}0.829 \\
(1.380)\end{array}$ & $\begin{array}{l}-2.085^{*} \\
(1.172)\end{array}$ & $\begin{array}{l}1.031 \\
(1.386)\end{array}$ & $\begin{array}{l}-1.971 \\
(1.821)\end{array}$ \\
\hline Constant & $\begin{array}{l}9.445^{*} \\
(5.395)\end{array}$ & $\begin{array}{l}32.002^{* * *} \\
(4.354)\end{array}$ & $\begin{array}{l}56.213^{* * *} \\
(3.674)\end{array}$ & $\begin{array}{l}31.742^{* * *} \\
(4.363)\end{array}$ & $\begin{array}{l}-15.937 * * * \\
(5.746)\end{array}$ \\
\hline $\begin{array}{l}\text { Observations } \\
\text { R-squared }\end{array}$ & $\begin{array}{l}565 \\
0.14\end{array}$ & $\begin{array}{l}567 \\
0.07\end{array}$ & $\begin{array}{l}597 \\
0.03\end{array}$ & $\begin{array}{l}565 \\
0.07\end{array}$ & $\begin{array}{l}567 \\
0.03\end{array}$ \\
\hline
\end{tabular}


Table 4: First-Stage 2SLS (Instrumental Variable) Estimates

\begin{tabular}{|c|c|c|c|c|c|c|c|c|c|}
\hline & (1) & (2) & (3) & (4) & (5) & (6) & (7) & (8) & (9) \\
\hline & $\begin{array}{c}\text { Freq } \\
\text { parental } \\
\text { praise }\end{array}$ & $\begin{array}{c}\text { Freq } \\
\text { par. read } \\
\text { to child }\end{array}$ & $\begin{array}{c}\text { Freq of } \\
\text { cultural } \\
\text { events }\end{array}$ & $\begin{array}{l}\text { Freq of } \\
\text { parental } \\
\text { criticism }\end{array}$ & $\begin{array}{c}\text { Allowance } \\
\text { in primary } \\
\text { school }\end{array}$ & $\begin{array}{c}\text { Allowance } \\
\text { for task } \\
\text { only }\end{array}$ & $\begin{array}{c}\text { Reward } \\
\text { for acad } \\
\text { effort }\end{array}$ & $\begin{array}{c}\text { Received } \\
\text { Car } \\
\text { as gift }\end{array}$ & $\begin{array}{l}\text { Parents } \\
\text { helped } \\
\text { Cheat }\end{array}$ \\
\hline \multirow[t]{2}{*}{ IQ Percentile } & -0.001 & -0.001 & 0.002 & $-0.002^{*}$ & $-0.084 * * *$ & 0.000 & $-0.001 *$ & -0.001 & 0.000 \\
\hline & $(0.001)$ & $(0.001)$ & $(0.001)$ & $(0.001)$ & $(0.027)$ & $(0.001)$ & $(0.001)$ & $(0.001)$ & $(0.000)$ \\
\hline \multirow{2}{*}{ Father Income } & 0.001 & 0.002 & $0.076 * * *$ & $-0.076^{* * *}$ & $1.921 * * *$ & $-0.033 * *$ & 0.001 & $0.061 * * *$ & 0.001 \\
\hline & $(0.026)$ & $(0.027)$ & $(0.026)$ & $(0.026)$ & $(0.548)$ & $(0.014)$ & $(0.012)$ & $(0.014)$ & $(0.007)$ \\
\hline \multirow[t]{2}{*}{ Mother Income } & -0.006 & -0.027 & 0.023 & 0.029 & 0.321 & $-0.025^{*}$ & 0.009 & 0.007 & -0.001 \\
\hline & $(0.027)$ & $(0.028)$ & $(0.026)$ & $(0.026)$ & $(0.565)$ & $(0.014)$ & $(0.012)$ & $(0.014)$ & $(0.007)$ \\
\hline \multirow[t]{2}{*}{ Father Education } & $0.092 *$ & $0.151^{* * * *}$ & $0.142^{* * *}$ & -0.055 & $-2.702 * * *$ & 0.032 & 0.000 & 0.006 & 0.015 \\
\hline & $(0.049)$ & $(0.051)$ & $(0.049)$ & $(0.048)$ & $(1.036)$ & $(0.026)$ & $(0.022)$ & $(0.026)$ & $(0.013)$ \\
\hline \multirow[t]{2}{*}{ Mother Education } & $0.107 * *$ & $0.306^{* * *}$ & $0.217^{* * *} *$ & -0.007 & $1.995^{*}$ & $0.063 * *$ & 0.014 & -0.010 & -0.008 \\
\hline & $(0.053)$ & $(0.055)$ & $(0.053)$ & $(0.053)$ & (1.135) & $(0.029)$ & (0.024) & $(0.029)$ & $(0.014)$ \\
\hline \multirow{2}{*}{ Number of Siblings } & $-0.093^{* * *}$ & $-0.092^{* * *}$ & $-0.082 * * *$ & -0.030 & $1.027 *$ & 0.007 & -0.016 & -0.020 & 0.001 \\
\hline & $(0.026)$ & $(0.027)$ & $(0.025)$ & $(0.025)$ & $(0.536)$ & $(0.014)$ & $(0.012)$ & $(0.014)$ & $(0.007)$ \\
\hline \multirow[t]{2}{*}{ Asian } & $-0.489 * * *$ & $-0.792 * * *$ & $-0.350^{* * *}$ & $0.303^{* * *}$ & -0.394 & $-0.229 * * *$ & $0.073^{*}$ & $-0.110^{* *}$ & 0.009 \\
\hline & $(0.085)$ & $(0.088)$ & $(0.084)$ & $(0.084)$ & $(1.790)$ & $(0.046)$ & $(0.038)$ & $(0.046)$ & $(0.023)$ \\
\hline \multirow[t]{2}{*}{ Black } & 0.112 & -0.071 & 0.110 & 0.015 & -3.577 & -0.131 & $0.104^{\prime}$ & -0.085 & 0.011 \\
\hline & $(0.176)$ & $(0.186)$ & $(0.175)$ & $(0.174)$ & $(3.760)$ & $(0.094)$ & $(0.079)$ & $(0.094)$ & $(0.047)$ \\
\hline \multirow[t]{2}{*}{ Latino } & 0.077 & $-0.445^{* * *}$ & $-0.233^{*}$ & -0.008 & -3.631 & $-0.117^{*}$ & 0.013 & 0.023 & -0.040 \\
\hline & $(0.127)$ & $(0.132)$ & $(0.126)$ & $(0.125)$ & $(2.670)$ & $(0.070)$ & $(0.057)$ & $(0.068)$ & $(0.033)$ \\
\hline \multirow[t]{2}{*}{ Constant } & $2.700 * * *$ & $2.098^{* * *}$ & $1.316^{* * *}$ & $2.365^{* * *}$ & 3.254 & $0.377 * * *$ & $0.176^{*}$ & $0.221^{* *}$ & 0.044 \\
\hline & $(0.201)$ & $(0.207)$ & (0.198) & (0.198) & (4.194) & (0.108) & $(0.090)$ & (0.107) & $(0.053)$ \\
\hline$F$-statistic $\dagger$ & 10.5 & 29.7 & 19.7 & 4.3 & 3.0 & 5.8 & 1.1 & 4.6 & 0.5 \\
\hline Observations & 568 & 569 & 570 & 571 & 550 & 553 & 569 & 567 & 567 \\
\hline R-squared & 0.13 & 0.30 & 0.23 & 0.06 & 0.06 & 0.08 & 0.02 & 0.06 & 0.01 \\
\hline
\end{tabular}

† The F-statistic is the test of the joint statistical significance of the excluded instruments in the first stage model.

Table 5: Second-Stage (Instrumental Variable) Estimates

\begin{tabular}{|c|c|c|c|c|c|}
\hline & (1) & (2) & (3) & (4) & (5) \\
\hline & GPA Percentile & $\begin{array}{c}\text { GPA } \\
\text { Percentile }\end{array}$ & $\begin{array}{c}\text { Level of } \\
\text { Acad. Effort }\end{array}$ & $\begin{array}{c}\text { Academic } \\
\text { Skill }\end{array}$ & Overachiever \\
\hline IQ Percentile & $\begin{array}{l}0.193 * * * \\
(0.059)\end{array}$ & & & & \\
\hline Level of Academic Effort & $\begin{array}{l}0.354 * * * \\
(0.092)\end{array}$ & & & & \\
\hline Freq read to child & $\begin{array}{l}19.705^{*} \\
(10.600)\end{array}$ & $\begin{array}{l}17.489 * \\
(10.147)\end{array}$ & $\begin{array}{l}-8.092 \\
(8.423)\end{array}$ & $\begin{array}{l}19.297^{*} \\
(10.352)\end{array}$ & $\begin{array}{l}11.574 \\
(12.090)\end{array}$ \\
\hline Freq parental praise & $\begin{array}{l}-18.045 \\
(14.732)\end{array}$ & $\begin{array}{l}-14.615 \\
(14.309)\end{array}$ & $\begin{array}{l}5.463 \\
(10.816)\end{array}$ & $\begin{array}{l}-17.958 \\
(14.467)\end{array}$ & $\begin{array}{l}-14.852 \\
(17.048)\end{array}$ \\
\hline Received a car as gift & $\begin{array}{l}23.736 \\
(17.348)\end{array}$ & $\begin{array}{l}17.794 \\
(16.504)\end{array}$ & $\begin{array}{l}-28.339 * \\
(15.132)\end{array}$ & $\begin{array}{l}19.992 \\
(17.277)\end{array}$ & $\begin{array}{l}-3.895 \\
(19.663)\end{array}$ \\
\hline Freq of cultural events & $\begin{array}{l}-5.288 \\
(9.730)\end{array}$ & $\begin{array}{l}-3.500 \\
(9.382)\end{array}$ & $\begin{array}{l}9.657 \\
(8.621)\end{array}$ & $\begin{array}{l}-4.022 \\
(9.906)\end{array}$ & $\begin{array}{l}3.172 \\
(11.178)\end{array}$ \\
\hline Constant & $\begin{array}{l}21.044 \\
(21.271)\end{array}$ & $\begin{array}{l}44.907^{*} \\
(23.694)\end{array}$ & $\begin{array}{l}50.002^{* * *} \\
(17.784)\end{array}$ & $\begin{array}{l}49.903^{* *} \\
(24.158)\end{array}$ & $\begin{array}{l}2.823 \\
(28.229)\end{array}$ \\
\hline Observations & 530 & 532 & 559 & 530 & 532 \\
\hline Cragg-Donald Wald Stat., $p$-value: & 0.2525 & 0.2251 & 0.1921 & 0.2131 & 0.2251 \\
\hline
\end{tabular}


Table 6: Three-Stage Least Squares Estimates - Student Achievements and Parental Behaviors

\begin{tabular}{|c|c|c|c|c|}
\hline & (1) & (2) & (3) & (4) \\
\hline & GPA Percentile & GPA Percentile & $\begin{array}{c}\text { Level of Acad. } \\
\text { Effort }\end{array}$ & Academic Skill \\
\hline IQ Percentile & $\begin{array}{l}0.682^{* * *} \\
(0.097)\end{array}$ & & & \\
\hline Level of Academic Effort & $\begin{array}{l}1.365^{* * *} \\
(0.221)\end{array}$ & & & \\
\hline Freq read to child & $\begin{array}{l}20.688 \\
(13.280)\end{array}$ & $\begin{array}{l}15.853^{*} \\
(8.619)\end{array}$ & $\begin{array}{l}-6.036 \\
(7.721)\end{array}$ & $\begin{array}{l}17.477^{* *} \\
(8.809)\end{array}$ \\
\hline Freq parental praise & $\begin{array}{l}-14.214 \\
(19.017)\end{array}$ & $\begin{array}{l}-10.457 \\
(12.379)\end{array}$ & $\begin{array}{l}3.874 \\
(11.089)\end{array}$ & $\begin{array}{l}-12.414 \\
(12.652)\end{array}$ \\
\hline Received a car as gift & $\begin{array}{l}27.128 \\
(23.587)\end{array}$ & $\begin{array}{l}4.087 \\
(15.115)\end{array}$ & $\begin{array}{l}-20.962 \\
(13.539)\end{array}$ & $\begin{array}{l}7.554 \\
(15.449)\end{array}$ \\
\hline Allowance (\$) & $\begin{array}{l}-10.526 \\
(12.890)\end{array}$ & $\begin{array}{l}-2.145 \\
(8.347)\end{array}$ & $\begin{array}{l}6.658 \\
(7.477)\end{array}$ & $\begin{array}{l}-3.698 \\
(8.531)\end{array}$ \\
\hline Freq of cultural events & $\begin{array}{c}-63.015^{*} \\
(35.496)\end{array}$ & $\begin{array}{l}39.135^{*} \\
(21.119)\end{array}$ & $\begin{array}{l}53.586 \text { *** } \\
(18.918)\end{array}$ & $\begin{array}{l}42.782^{* *} \\
(21.585)\end{array}$ \\
\hline Constant & $\begin{array}{l}0.682^{* * *} \\
(0.097)\end{array}$ & & & \\
\hline Observations & 514 & 514 & 514 & 514 \\
\hline
\end{tabular}

